\title{
Preliminary Investigations of the Cause of Post-harvest Fungal Rot of Tomato.
}

\author{
${ }^{1}$ Ukeh, Jude A and ${ }^{2}$ Chiejina, Nneka V. \\ ${ }^{1,2}$ Department of Plant Science and Bitechnology University of Nigeria, Nsukka.
}

\begin{abstract}
Diseased tomato (Lycopersicon esculentum L.) fruits (variety Roma) obtained from a local market in Nsukka were investigated for the cause of rot found in them. Isolations were made from the diseased fruits and diseased tissues were plated in Potato Dextrose Agar (PDA) plates. Pure cultures were obtained by several aseptic transfers of colony growth from the PDA plates to clean PDA plates. Identifications of isolated fungal pathogens were made based on cultural characteristics and microscopic examinations of the cultures. The following pathogens were identified; Helminthosporium solani, Aspergillus niger, Penicillium digitatum and Mucor piriformis. A .niger had the highest percentage frequency of occurrence followed by M. piriformis, and the former was the most virulent. Work is in progress for the use of extracts of Aframomum melegueta and Zingiber officinale as antifungal agents for the control of the pathogens.
\end{abstract}

Keywords: Tomato, Post harvest, Rot, Pathogens.

\section{Introduction}

Tomato (Lycopersicon esculentum L.) family Solanaceae is an important commercial crop in the world. Nutritional values of tomato make it a widely accepted vegetable by consumers. Nevertheless, tomato is a very perishable vegetable with a short shelf-life and high susceptibility to fungal diseases (Coursey, 1983). During prolonged storage, tomato is susceptible to post harvest diseases caused by various pathogenic fungi.

Many fruits are perishable especially in tropical and subtropical regions without adequate refrigeration (Coursey 1983). The magnitude of post harvest losses in fresh fruits is estimated to be $25.80 \%$ (Thirupathi et al., 2006). Most of the product is lost after the harvest because of inadequate handling and preservation methods, (Wills et al., 1981; Liu and Ma, 1983) and also it is extremely difficult to harvest fresh tomatoes without causing injuring.

Tomatoes are served as either raw or cooked and in various processed food materials, such as in salads, drinks, paste, puree, ketchup, whole peeled tomato, etc. The tomato fruits give abundant and well-balanced nutrition consisting of minerals (potassium, magnesium, calcium, iron and zinc), vitamins $\left(A, B_{1}, B_{2}, C\right.$ and $E$ ), dietary fiber (pectin) and citric acid. In addition, the red pigment (lycopene), which tomato fruit contains substantially, has recently attracted interest, because lycopene has high antioxidant ability against oxygen radicals that probably cause cancer, aging and arteriosclerosis. Thus, tomato contributes to our enjoyable diet and good health all over the world.

Post harvest diseases destroy 10-30\% of the total yield of crops and in some perishable crops like tomato especially in developing countries, they destroy more than 30\% of the crop yield (Kader, 2002; Agrios, 2005). The quality of tomato is affected by post-harvest handling, packaging, transportation and storage which may result in decay and production by micro organisms which become activated because of the changing physiological state of the fruit (Wilson et al., 1991). Fruits, due to their low $\mathrm{pH}$, high moisture content and nutrient composition are very susceptible to attack by pathogenic fungi, which in addition to causing rots, may also make them unfit for consumption by producing mycotoxins (Stinson et al., 1981; Philips, 1984; Moss, 2002).

Fungi are the most important and prevalent pathogens, infecting a wide range of host plants and fresh fruits causing destructive and economically important losses in them during transportation and storage (Sommer, 1985).

This work was targeted at isolating and identifying fungal pathogens responsible for post harvest rot of tomato with a view of advancing control measures.

\section{Collection of Tomato Fruits}

II. Materials And Methods

Infected tomato (Lycopersicon esculentum) fruits were purchased from Onuiyi market in Nsukka Local Government Area of Enugu State. 


\section{Sterilization}

Autoclavable materials such as agar were aseptically sterilized in an autoclave at $121^{0} \mathrm{C}$ for 15 minutes. Petri dishes, beakers, test tubes, filter papers, and metalic materials such as spatula and forceps were sterilized using hot air oven at a temperature of $160^{\circ} \mathrm{C}$ for 1 hour. The wire loops were also sterilized until red hot and allowed to cool before using $70 \%$ alcohol to wipe the work tops to prevent contamination.

\section{Preparation of Culture Media}

All culture media were prepared according to instructions by manufacturers' and autoclaved at $121^{\circ} \mathrm{C}$ for 15 minutes.

\section{Isolation of Fungal Isolates}

The isolation technique used was the same as that used by Chiejina (2008). Thin sections $(2 \mathrm{~mm}$ diameter) were cut from the periphery of diseased tomato fruits and sterilized in $0.1 \%$ mercuric chloride for 2 minutes. These sections were rinsed in 3 changes of sterile distilled water and plated in Potato Dextrose Agar (PDA) plates. The plates were incubated at room temperature $\left(27^{0} \mathrm{C} \pm 2^{\circ} \mathrm{C}\right)$ for 7 days. Pure cultures were obtained by several transfers of the colony growth from PDA plates to clean PDA plates aseptically.

\section{Determination of percentage of fungal occurrence}

This was done to determine the frequency of occurrence of the different fungal isolates. Isolations were made different diseased tomato fruits and were cultured differently. The number of occurrence for each of the isolates in the eight different fruits were recorded, calculated and expressed as percentage.

Percentage of occurrence $=\mathrm{X} / \mathrm{N} \times 100 / 1$

$\mathrm{X}=$ Total number of each organism in all the fruits

$\mathrm{N}=$ Total number of the entire organism in all the fruits screened.

\section{Pathogenicity Tests}

A pathogenicity tests were carryout using techniques of Okigbo et al (2009). Healthy tomato fruits were washed in sterile distilled water and surface sterilized with $0.1 \%$ mercury chloride solution. A razor blade was used to cut the fruits and then culture of the isolates were introduced into the open cut and replaced with the core. These were kept for 24 to 72 hours. On establishment of disease symptoms, inoculum from the infected fruits were taken and cultured. Pure cultures were identified according to (Barnett and Hunter, 1999; Alexopoulos et al., 2002). The symptoms were identical to those of naturally infected tomatoes. Morphological characteristics of conidia and mycelia of the fungi that were reisolated from inoculated fruits confirmed Koch's postulates.

\section{Identification}

The pure culture isolates obtained from the diseased tomato fruits were used for identification purposes. Each isolate was subjected to colony and microscopic examinations during which their structural features were observed.

Identification of fungi was based on the growth patterns, colour of mycelia and microscopic examinations of vegetative and reproductive structures according to (Barnett and Hunter, 1999; Alexopoulos et al., 2002).

\section{Results}

The investigation revealed that Helminthosporium solani, Aspergillus niger, Mucor piriformis and Penicillium digitatum were responsible for the post harvest rot of Tomato fruits in Nsukka. Pathogenicity tests confirmed that, these fungal isolates were the causal agents of the rot.

In this study, Aspergillus niger, Helminthosporium solani, Penicillium digitatum and Mucor piriformis has been implicated in post-harvest rot of tomato fruits. A niger with multiconidia and big vesicle (Plate 3 had the highest percentage frequency of occurrence follow by M. piriformis (table 1), with A. niger being the most virulent of all pathogens isolated.

Penicillium digitatum produce multiple spores or conidia on long stalks called phalids (Plate 4). Penicillium digitatum appear greenish blue on PDA plates. Spore sizes of A. niger are similar to those of Penicillium digitatum (about $2-5 \mathrm{~cm}$ ), the pathogen (A. niger) appear black on PDA.

Helminthosporium solani appear dark and paler at the growing tip on PDA. Phalids are long crooked with multiseptate conidia attach at the curved points. Conidia are curved and tapering at ends (Plate 2).

Mucor piriformis belong to the family mucoraceae of the order mucorales in the class zygomycetes and occur typically as saprophytes in soil and dung. Colonies of Mucor piriformis grown on PDA were white at first turning brownish to gray with age and become heavily speckled with the appearance of sporangia (Plate 1). 
Table 1. Percentage frequency of occurrence of fungi on diseased tomato fruits.

\begin{tabular}{lc}
\hline Isolates & Frequency of occurrence (\%). \\
\hline Helminthosporium solani & 11.11 \\
Aspergillus niger & 38.89 \\
Penicillium digitatum & 22.22 \\
Mucor piriformis & 27.78 \\
\hline
\end{tabular}

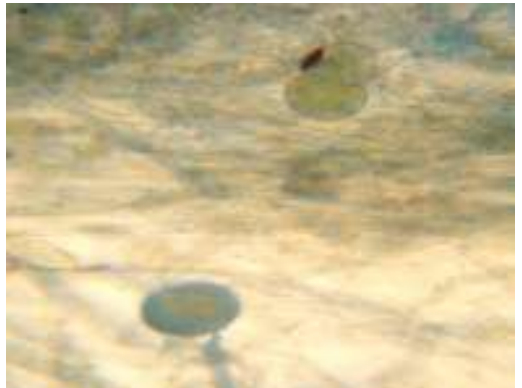

Plate 1: Mucor piriformis with sporangia attached to sporangiophore.

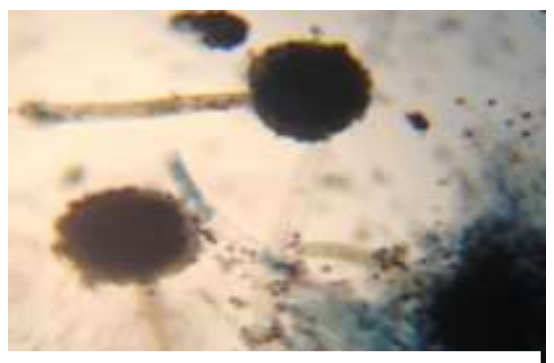

Plate 3: Aspergillus niger with conidia attached to conidiophore.

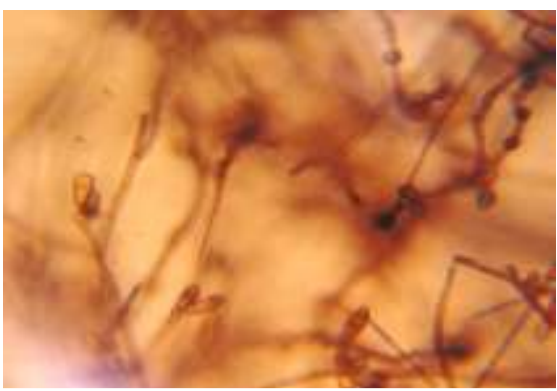

Plate 2: Helminthosporium solani with multiseptate conidia attached at the curved noint.

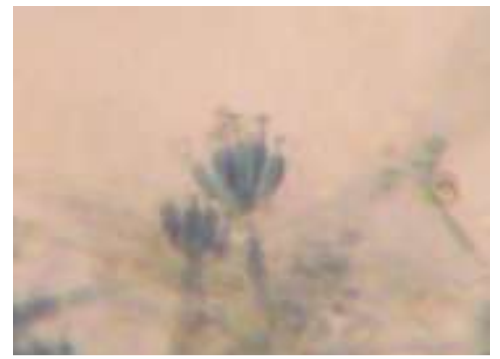

Plate 4: Penicillium digitatum

With conidia on long stalk phalides.

IV. Discussion

Four fungal pathogens were isolated from the tomato fruits indicating that these pathogens could grow and survive in tomato fruits. These pathogens were the causal agents of post harvest rot of tomato fruits in Nsukka, Enugu State. This is probably due to the fact that tomato fruits contain some nutrients suitable for the growth of pathogens. The spoilage of the fruits during post-harvest storage is due to infection by these micro organisms which might have gained entry through stomata openings, growth cracks or surface injuries (Wills et al., 1981). These pathogens also gained entry through injuries caused by rough handling, poor road and storage facilities (Liu and Ma, 1983).

Fruits may be infected when green and small, but do not show any marked lesions until they begin to ripen. The disease mostly affects only ripe fruit. At first, infected fruits show small, slightly sunken, watersoaked spots. These spots enlarge, become darker in colour, sunken and have concentric rings until the entire fruit is consumed by the rot. Losses caused by post-harvest diseases have increased recently than generally realised because the value of fruits and vegetables has increased (Eckert and Sommer, 1967). Splittstoesser, (1987) reported that species of Penicillium, Aspergillus and Mucor are common post-harvest fungi. Also Aspergillus niger, Mucor spp, and $P$. digitatum were found to cause rot of cassava (Okigbo, et al., 2009). These were implicated as pathogen when tested on healthy products. This work agreed with Agrios, (2005).

M. piriformis is a soil borne pathogen, it enters packing facilities through infested soils or organic debris adhering to field bins. M. piriformis may infect the stem, calyx or wounds on the skin of fruit. Mucor rot originates primarily from infection of wounds on the skin of fruit stem end. Mucor rot is also seen on pear and apples (Michailides and Spotts, 1990). M. piriformis has become a serious threat for fruits in cold storage medium. Recently, Mucor species were of relatively minor importance as post harvest pathogens. In the last two decades, however, they have caused serious decay of strawberries, pears, apples, guavas, tomato and sweet potato (Michailides and Spotts, 1990).

Helminthosporium spp was found to be the causal agent of Potato tubers rot on storage. Mehrotra and Aggarwal (2003) also confirmed Helminthosporium spp as a pathogen that caused post harvest rot of tomato. These may lead to losses in edibility, nutritional quality, caloric value and consumer acceptability of the products. 
Some of the moulds from these pathogens could produce mycotoxins while growing on fruits (Stinson et al., 1981). Kurup, (2003) stated that these pathogenic fungi on the other hand, could cause infections or allergies in susceptible individuals.

The most serious post harvest diseases are those that cause rapid and extensive breakdown of crops that are high in moisture content and nutrients. It has been estimated by Liu and Ma (1983) that, 30\% of all fruits rots are caused by a species of Penicillium. In this work, Aspergillus niger and Penicillium digitatum are the most virulent pathogens.

These pathogens infect tomato fruits during prolonged periods of rainfall and high humidity, especially when fruits are wrongly packaged. Fruit rot can occur from the fruit set to harvest period. It is impossible to completely eliminate post-harvest losses. Whereas it is possible and better to reduce them by $50 \%$ to $60 \%$ (Kader, 2002). Reducing post-harvest loss of fruits that have already been produced is more sustainable and environmentally sounds than increasing production areas to compensate for these losses (Kader, 2002).

Work is in progress for the use of extracts from Aframomum melegueta and Zingiber officinale as antifungal agents against the isolated and identified pathogens.

\section{References}

[1] Agrios, G.N. (2005). Plant Pathology. Academic Press, New york. 922pp.

[2] Alexopoulos, C. O., Mims, C.W. and Blackwell, M. (2002). Introductory Mycology.

[3] ( $4^{\text {th }}$ edition). John Wiley and Sons Inc. Singapore, $869 \mathrm{pp}$.

[4] Barnett, H.L. and Hunter, B.B. (1999). Illustrated Genera of Imperfect Fungi, (4 ${ }^{\text {th }}$ edition). The American Phytopathological Society . St. Paul, Minnessota,USA, 218pp.

[5] Chiejina, N.V. (2008). Mycoflora of some salad vegetables. Bio-Research.6(2):392-395.

[6] Coursey, D .G. (1983). Postharvest losses in perishable foods of the developing world, pp485-515. In: Postharvest Physiology and Crop preservation, (ed) Liberman M. Plenum Press, NY. 515pp

[7] Eckert, J. W. and Sommer, N.F. (1967) Control of diseases of Fruits and Vegetables by Post-harvest Treatment. Annual Review Plant Pathology 5:391-432

[8] Kader, A.A. (2002). Post-harvest Technology of Horticultural crops. University of California, Agriculture and Natural Resources. 535pp.

[9] Kurup, V.P. (2003). Fungal Allergens. Curr. Allergy Asthma Rep 3:416-423.

[10] Liu, M.S. and Ma, P.C. (1983). Post-harvest problems of vegetables and fruits in the

[11] Tropics and subtropics. Asian Vegetable Research and Development Center.

[12] $0^{\text {th }}$ Anniversary monograph Series. Taiwan, China.14pp.

[13] Mehrotra, R. S. and Aggarwal, A. (2003). Plant pathology. $2^{\text {nd }}$ Ed. Tata McGraw- Hill. New Delhi. 846pp.

[14] Michailides, T. J. and Spotts, R. A. (1990). Postharvest diseases of pome and stone fruits caused by Mucor piriformis in the Pacific Northwest and California. Plant Diseases 74:537-543.

[15] Moss, M.O. (2002). Mycotoxin Review. 1. Aspergillus penillium. Mycologist, 16:116-119.

[16] Okigbo, R.N., Ramesh P. and Achusi, C.T (2009). Post-Harvest Deterioration of Cassava and its Control Using Extracts of Azadirachta indica and Aframomum melegueta. E-Journal of Chemistry 6(4), 1274-1280.

[17] Phillip, D.J. (1984). Mycotoxins as a post-harvest problem, pp50-54. In: Post-harvest pathology of fruits and vegetables; Postharvest losses in perishable crops. Moline, H.E. (ed). Agricultural experimental station. University of California, Berkeley Publications. NE. 461pp.

[18] Sommer, N.F. (1985). Strategies for control of post-harvest diseases of selected commodities, pp83-98. In: post-harvest Technology of Horticultural Crops. University of California Press. 246pp.

[19] Splittstoesser, D.F (1987). Fruits and fruit Products. Pp101-128. In: Food and Beverage Mycology. Beuchat, L. (ed). Van Nostrand Reinhold, New York. 591pp.

[20] Stinson, E.E., Osman, S.F., sHeisler, E.G., Sicihano, J. and Bill, D.D. (1981). Mycotoxin production in whole tomatoes, apples oranges and lemons. Journal of Agriculture and Food Chemistry.29:790-792.

[21] Thirupathi, V. Sasikala, S. and John Kennedy, Z. (2006). Preservation of fruits and vegetables by wax coating, pp1-10. In: Science Technology Enterpreeur. (Mittal, H.K. et al) (eds) NSTEDS, DST. Delhi.

[22] Wills, R.H, Lee, T.H., Graham, D., Mcglassom, W.B and Hall, E.G. (1981). An Introduction to the physiology and handling of fruits and vegetables. London. NY . 432pp.

[23] Wilson, C.L., Wisiniewski, M.E., Biles, C.L., Mclaughlin, R., Chalutz, E. and Droby, S. (1991). Biological control of post-harvest diseases of fruits and vegetables: alternative to synthetic fungicides. Crop Protection. 10:172-177. 